\title{
Circulation as a Basic of Animal Sheep Design in Gianyar-Bali
}

\author{
I Made Angga Dhimas Asthabayuㄹ, Putu Rumawan Salain², Ida Bagus Gde Primayatna ${ }^{3}$
}

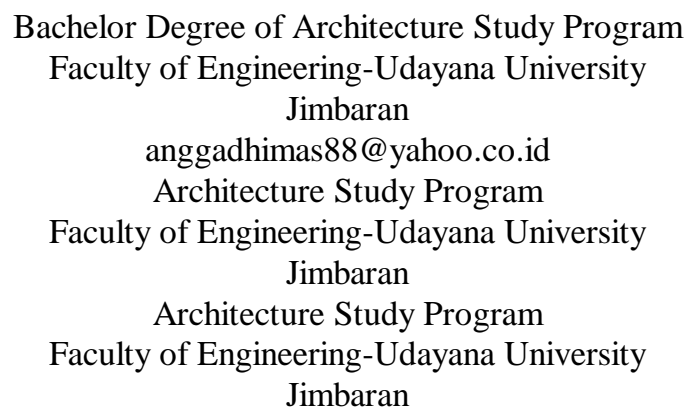

\begin{abstract}
Gianyar Regency has a arrractive tourist destinations for visitor domestic and foregin visitor. In addition society and vis-itors have a rate of consumption of beef or pork are quite high, where the Gianyar Regency has no industry to accom-modate animal cuts service to meet the needs of consumers will be the meat. One offort to accommodate the need of the meat is the establishment of industry and services in the form of Slaughterhouse Animals that would later embody the need for meat in Gianyar Regency. Circulation as the Basis for the design of the RPH has a pupose to provide comfort on visitors or animals. Which would later effect the comfort of the visitors and the result will be the meat of the animal after the cut. Circulation as the basis for the design of Slaughterhouse Animal in Gianyar describe using the methods of analysis comparisons against Animal Slaughterhouse design ang evaluation methods. After analyzing the in accordance with the discussion against on the design of this, carried outan evaluation to find out how circulation pat-terns on an industry are. So that in the future, the result of the evaluaton will be useful as a reference in designing an industrial area especially in the design of Slaughterhouse Animals.
\end{abstract}

Index Terms - Circulation, Design, Slaughterhouse Animals.

\section{INTRODUCTION}

In the current global era, Indonesian livestock production is demanded to be able to compete not only in the country but also especially to seize the international market. Consumers at home and abroad are increasingly demanding quality requirements guaranteed both residue free product requirements, both for biological substances, chemicals, pesticides, heavy metals, antibiotics, hormones, and other drugs, as well as for contamination microbes that can transmit diseases, as well as having good quality, will be met if there is close supervision from cultivation techniques, feeding and medicines, and their distribution to consumers
[1].

In Bali, especially in Gianyar Regency, beef and pork have become the daily food needs of residents and tourists in Gianyar Regency. The circulation of beef and pork consumption in 2017 is one third of the population and tourism in Gianyar Regency, namely for beef as many as 175,656 people / day and for pork as much as 172,499 people / day. According to preliminary observations, several RPHs in Gianyar Regency currently have shortcomings in terms of cutting capacity, building materials, and the layout of buildings that are not standardized by the Director General of Veterinary Public Health. Therefore to accommodate the need for meat in Gian-yar Regency, the Gianyar Regency Government is required to establish a Slaughterhouse that will later facilitate farmers to process their livestock into meat [2]. 


\section{RESUlt AND ANALISYS}

\section{A. Slaughterhouse}

Slaughterhouse or better known as RPH is an industry and service that has an important role in maintaining public interests in terms of health. The definition of RPH itself is a building complex with a specific design that is used as a place for slaughtering animals properly for consumption by the wider community and must meet the criteria of safe, healthy, intact, and highly competitive. Animal Slaughterhouse has been regulated in a law that has been established by the Director General of Veterinary Public Health [1] as follows: (a) Law Number 18 Year 2009 article 61 paragraph (3) concerning Animal Husbandry and Health; (b) Government Regulation Number 22 of 1983 concerning Veterinary Public Health; (c) Government Regulation No. 28/2004 concerning Safety, Quality, Food Nutrition.

\section{B. Location}

The site of the site that will be built to establish slaughterhouses is located on Jalan Prof. Dr. Ida Bagus Mantra, Sukawati District, Gianyar-Bali

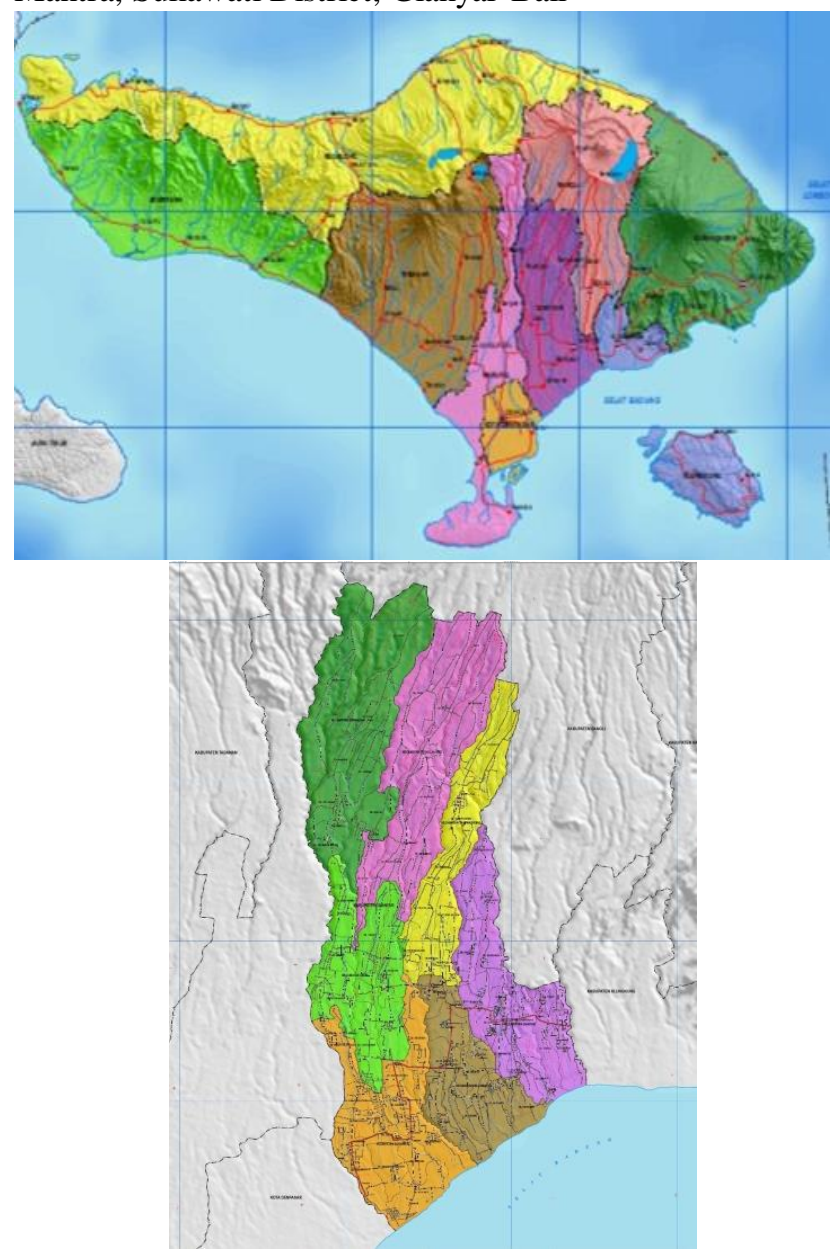

Fig. 1. Location of the RPH (source: Asthabayu:2017)

\section{Sirculation}

According to [3] circulation describes a pattern of movement, both vehicles and pedestrians above and around the site that affect the duration and the peak load for traffic and pedestrians. Circulation is the movement of space, the path of circulation is defined as a rope that is seen connecting spaces in maupung outer space, therefore we move in time through the stages of space. At the same source, Ching mentioned several circulation patterns as follows:

Linear pattern, all roads are linear, straight roads can be the main organizing element for a row of spaces. In addition, the road can be curved or consist of segments, cut other roads, branch off, form a figure (loop).

Radial, radial forms have a path that develops from or stops at, a center, a common point

Spiral, a spiral form is a continuous path that originates from the central point, rotating around it with a changing distance.

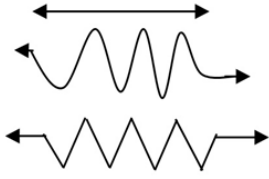

Pola Linier

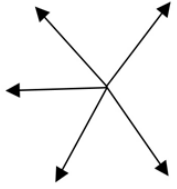

Pola Radia

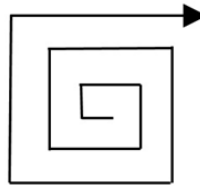

Pola Spiral
Fig. 2. Sirculation Pattern (source: Asthabayu:2017)

\section{Wastewater Circulation}

Wastewater is waste water (used water or dirty water) from clean water that has been used. Before wastewater is discharged, wastewater should be treated first. To facilitate treatment, wastewater should be divided according to pollution: soap water, rain water, and water phases so that each waste water can be treated separately as needed.

\section{E. Human Vehicle Circulation and Site Circulation}

The entrance of the visitor's vehicle and also the animal transport vehicle are put together, which in and out are at one entrance. But for the entrance of cows separated from pigs, because it has been stipulated by the Director General of Kesmavet rules regarding not being allowed to become one. Furthermore, circulation within the site uses a linear circulation pattern in order to reduce the risk of congestion within the site.

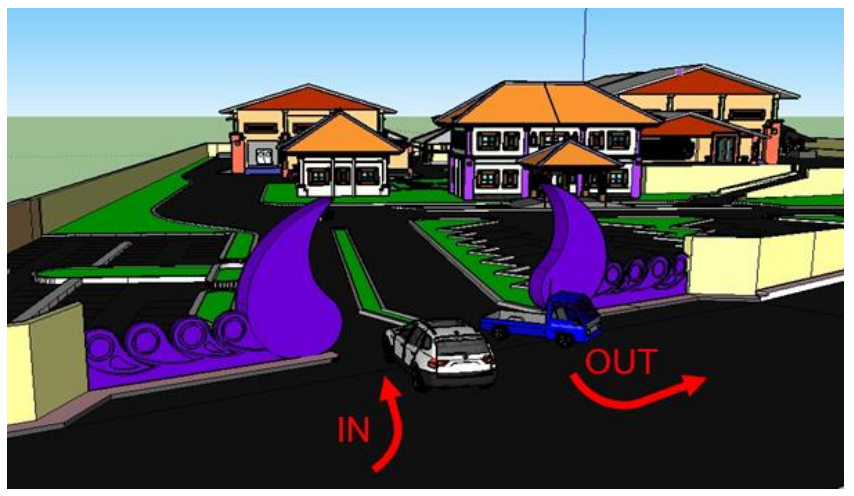




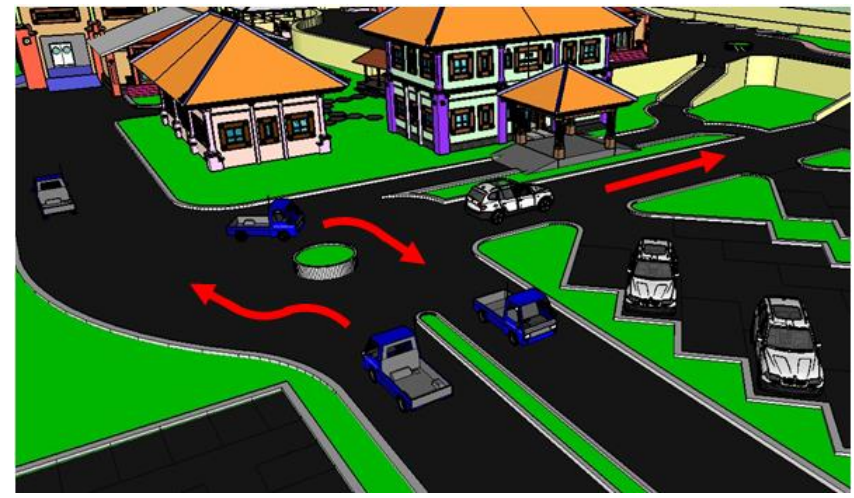

Fig. 3. Multi-level Circulation (source: Asthabayu:2017)

\section{F. Open Space Circulation Parking Area}

Vehicle parking at the site is divided into three parts, namely: parking of management vehicles and visitors into one placed at the front of the office building so that access to the office becomes easier, parking of cattle transport vehicles and parking of pig transport vehicles are made separately, for vehicles cow transporters are located close to the cow resting cages and the parking of pig transport vehicles is placed close to the pig resting cages with the aim of making it easier for cattle and pig transport vehicles to drop off animals in the loading dock area. Each parking uses a linear circulation pattern and uses 45 degree parking.

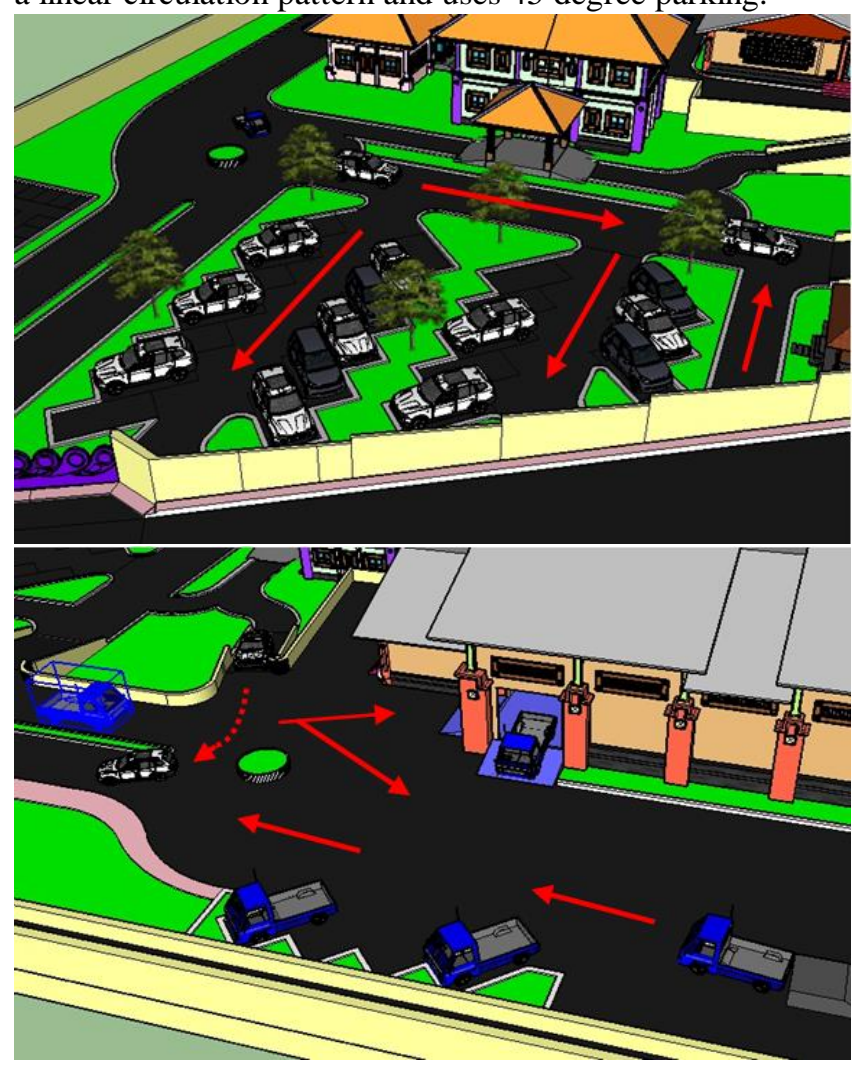

Fig. 4. F. Open Space Circulation Parking Area (source: Asthabayu:2017)

\section{G. Animal Circulation in the Rest Enclosure}

After the farmer enters the RPH, the farmer will be directed by a marker in the form of a statue to the resting area. In the animal resting area to be cut down, the loading dock area has the same height as the floor of the animal carrier truck. It is intended that animals do not jump when down the truck and after the animals go down will be weighed directly in the loading dock area.

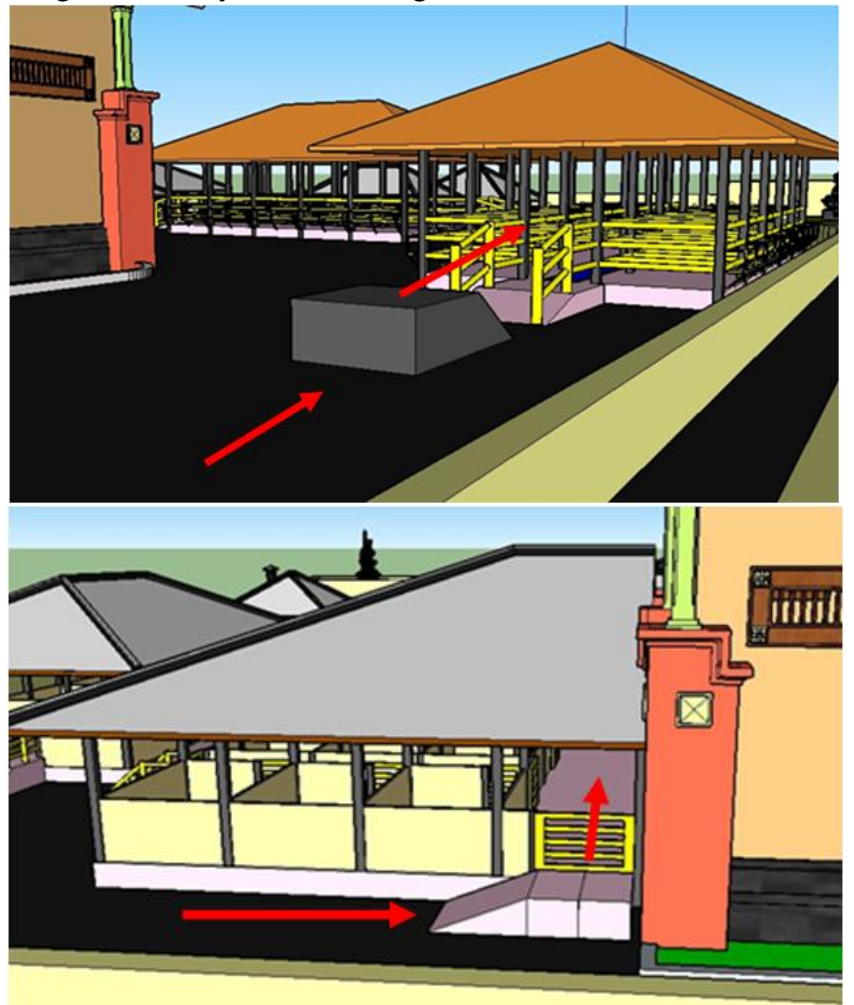

Fig. 5 G. Animal Circulation in the Rest Enclosure (source: Asthabayu:2017)

\section{H. Limiting and herding animals in rest cages}

Limiting the resort cage uses iron which is given a layer of paint so it does not rust quickly. Why use iron, because iron is a material that is easily processed so that the cattle in it do not feel pressured and do not experience stress that can interfere with the meat after being cut.

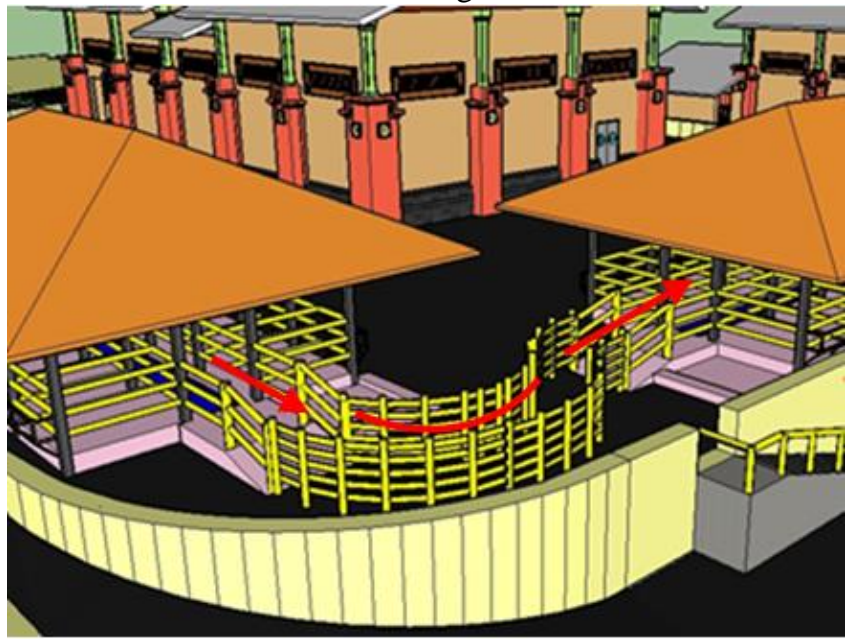




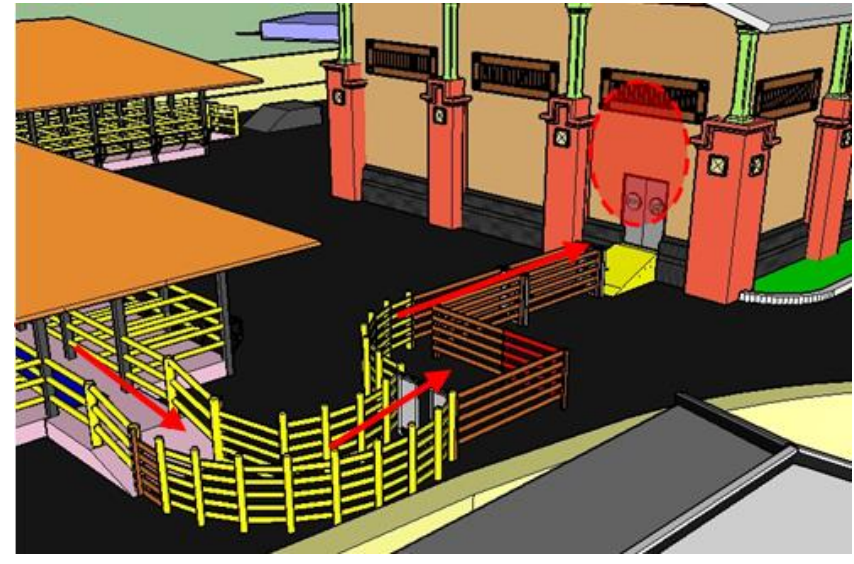

Fig. 6. Railing As Limiting and Animal Guiding

The flow of animal circulation continues into the abattoir (RPH) building. There are some spaces needed, among others; (1) Restraining box space; (2) the slaughter room; (3) Troubleshooting rooms; (4) Cleavage space; (5) Stomach Content Processing room; (6) Karkas Withering Room; (7) Meat and Bone Separation Room. These spaces are enclosed spaces so as not to be contaminated with outside air and will produce meat that is hygienic and is also good for public consumption. In addition, slaughtered animal flesh will be hung on a hanging railing that has been provided and will be led to the next rooms. After the meat is withered in the carcass withering room, it will be followed by meat and bone dissection and then the meat is ready to be taken back by the beef voters and the meat area of the meat dock.

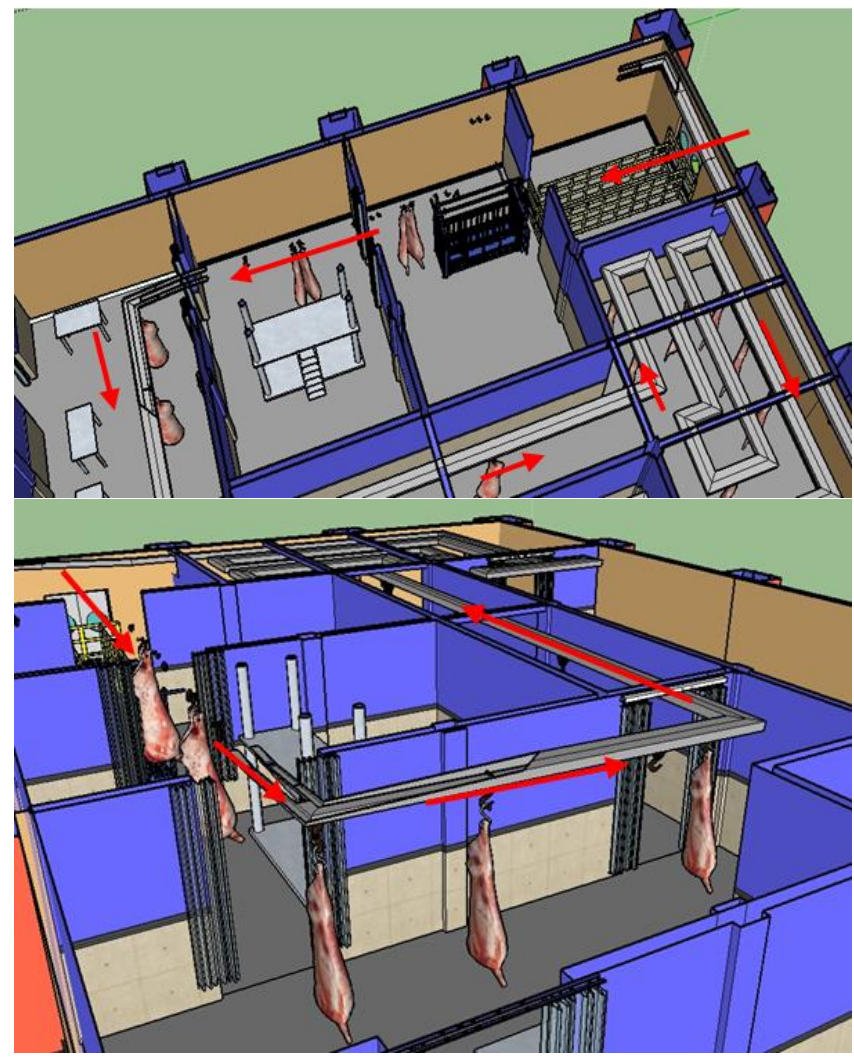

Fig. 7. Circulation of Restrainingbox Room and Slaughter Room (source: Asthabayu:2017)

Circulation used in the room above (figure 7) is a linear circulation pattern, where in the restraining box room cattle and pigs will be checked again, and continued with the animal slaughter process. After the animal is slaughtered, it is continued in the cleavage room and stomach contents processing.

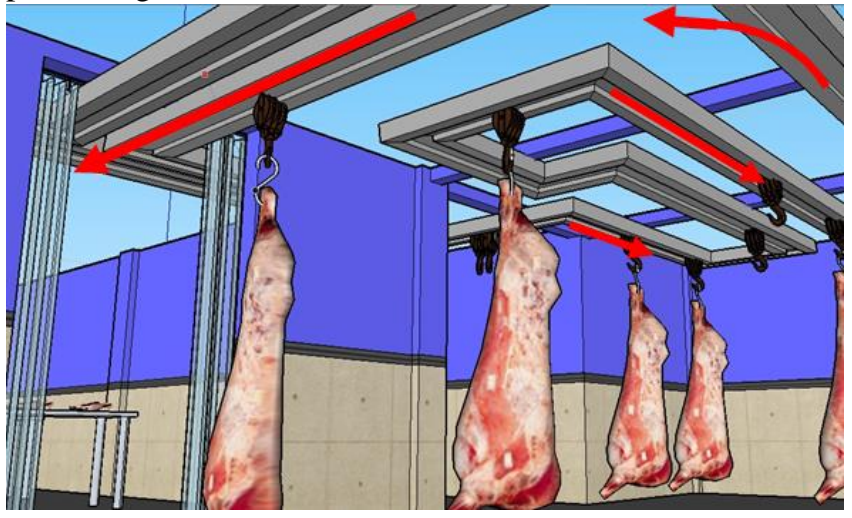

Fig. 8. Circulation in the Carcass Wither Room

Furthermore, after the contents of the stomach are removed, it will be carried out withering in the carcass withering space after the withered carcass will be continued the process of separating meat and bones. Thus the meat will be ready to be transported by the owner to the meat loading dock area.

\section{CONCLUSION}

Based on the explanation above, it can be concluded that the Slaughterhouse really needs to pay attention to circulation on the site and in spaces, this will provide convenience for visitors and breeders in circulating within the site. In addition, circulation also gives special attention to animals that will be slaughtered so that animals are not stressed, sick, and can produce unhealthy meat, because of some slaughterhouses in Bali, especially in Gianyar Regency, the law on slaughterhouses is not yet standardized. This is very influential on the results of animal processing in the form of meat, where meat must be hygienic, clean and halal.

\section{REFERENCES}

[1] Kesmavet, D., "Kiat Memilih Daging Yang Aman dan Sehat", Jakarta: Dirjen Bina Produksi Peternakan. 2009

[2] Wulansari, P., "Rumah Pemotongan Hewan (RPH) yang Higienis", 2011.

[3] Ching, F. D., "Arsitektur Bentuk, Ruang, dan Tatanan. In P. Sirkulasi, Arsitektur Bentuk, Ruang, dan Tatanan Edisi Ketiga", Jakarta: Erlangga, 1996 